\title{
A Proposed Pandemic Clause for Force Majeure Events under Construction Contracts in Malaysia
}

\author{
Shahrizal Mohd Zin ${ }^{1}$, Nur Ezan Rahmat' ${ }^{1}$ Abdul Mu'iz Abdul Razak', Nik Hasbi Fathi², \\ I Nyoman Putu Budiartha ${ }^{3}$
}

${ }^{1}$ Faculty of Law, Universiti Teknologi MARA, Shah Alam, Selangor, Malaysia

${ }_{2}^{N H F}$ Consulting, 20-1 Jalan USJ 1/1B, Subang Jaya, Selangor, Malaysia

${ }^{3}$ Faculty of Law, Universitas Warmadewa, Denpasar, Bali, Indonesia

shahriza@@uitm.edu.my, nurezan@uitm.edu.my, abdmuiz@uitm.edu.my, nik.nhf@gmil.com, budiarthaputu59@gmail.com Tel: 6019-3629556

\begin{abstract}
The construction industry is not spared from the adverse effect of the Covid-19 pandemic. This paper aims to identify the triggering events of Force Majeure under the standard forms of construction contract in Malaysia and determine the extent to which the relevant provisions in these contracts apply to the Force Majeure events during the pandemic. This research employs a qualitative research methodology, and the outcomes will help clarify the grey area of Force Majeure law caused by a global pandemic. It proposes guidelines to the construction industry when dealing with a similar disruption caused by an outbreak of the disease.
\end{abstract}

Keywords: pandemic clause, Force Majeure, construction contracts

eISSN: 2398-42870 2021. The Authors. Published for AMER ABRA cE-Bs by e-International Publishing House, Ltd., UK. This is an open access article under the CC BYNC-ND license (http://creativecommons.org/licenses/by-nc-nd/4.0). Peer-review under responsibility of AMER (Association of Malaysian Environment-Behaviour Researchers), ABRA (Association of Behavioural Researchers on Asians/Africans/Arabians) and CE-Bs (Centre for Environment-Behaviour Studies), Faculty of Architecture, Planning \& Surveying, Universiti Teknologi MARA, Malaysia.

DOI: https://doi.org/10.21834/ebpj.v6i16.2733

\subsection{Introduction}

The construction industry is one of the mainstays of a country's economic progress. Construction projects are increasingly complex, resulting in complex contract documents, and due to these, disputes are to be expected (Rahmat \& Abdul Rahim, 2020; Adebisi Raji, 2020). Recently, the Covid-19 pandemic has caused a significant impact on national and global economies at an unprecedented level which has seen massive closure of businesses and unemployment in years to come. The construction industry is also affected by the adverse effect of Covid-19. In this regards, various measures have been adopted to address the spread of Covid-19, which undoubtedly impacted the construction industry severely. Measures such as movement control order (MCO) have caused a delay in completing construction works due to the closure of the site, disruption to the program and manpower (Thamodaran \& Sri Kantha, 2020). When a delay occurs in a project, it will have adverse consequences on project objectives regarding time, cost and quality.

Since project delay during the pandemic is expected due to the government's MCO, a Force Majeure clause can be inserted into the construction contract. Force Majeure is a common clause in a construction contract drafted to protect the parties from liabilities if parties are prevented from performing their contractual obligations due to circumstances beyond their control (Abdul Hak et al., 2016). As there is no implied default protection for Force Majeure events, the absence of a specific provision in the contract will not excuse a

eISSN: 2398-42870 2021. The Authors. Published for AMER ABRA cE-Bs by e-International Publishing House, Ltd., UK. This is an open access article under the CC BYNC-ND license (http://creativecommons.org/licenses/by-nc-nd/4.0/). Peer-review under responsibility of AMER (Association of Malaysian Environment-Behaviour Researchers), ABRA (Association of Behavioural Researchers on Asians/Africans/Arabians) and CE-Bs (Centre for Environment-Behaviour Studies), Faculty of Architecture, Planning \& Surveying, Universiti Teknologi MARA, Malaysia.

DOI: https://doi.org/10.21834/ebpj.v6i16.2733 
party from liability due to events beyond their control. Hence, it is in the parties' interest to broaden or narrow the scope, criteria and extent of such triggering events in their contract. Since Force Majeure forms part of the risk allocation under a construction contract, close attention to the contractual wording needs to be given as the impacts of such a clause often vary depending on the forms of contract. A Force Majeure clause or provision is usually distinctive as there can be no implied Force Majeure definition. Therefore, to justify whether the Covid-19 outbreak is a Force Majeure event under a construction contract, the claiming party first need to prove that the event is within the criteria and/or list of occurring events. This is where the problem lies as most commonly used Malaysian standard forms of contract do not identify 'epidemic' or 'pandemic' as one of the specific event listed under its Force Majeure clauses.

Force Majeure will only apply if there is a Force Majeure clause in the contract. Without a Force Majeure clause, a party may have to fall back on frustration. A contract becomes frustrated when an event occurs, which has rendered it impossible or unlawful to perform the contractual obligations (Muhammad, 2020). For Miller (2020), Force Majeure excuses what would probably otherwise be a breach and electively suspends temporarily an obligation to perform the works. Force Majeure clauses tend to be interpreted literally, and they have been described as 'an exemption clause that must be construed strictly' (SHV Gas Supply \& Trading SAS v Naftomar Shipping \& Trading Co Inc [2006] 1 Lloyd's Rep 163). Force majeure clauses in contracts operate to manage legal risks between contracting parties by providing the outcome or reliefs if an event listed as part of a force majeure event triggered its implementation. It bears noting from the outset that this clause's operation applied strictly within its boundaries, and very little to no judicial flexibility has been afforded for the clause to be applicable beyond its very own list of events. (see the case of RDC Concrete Pte Ltd v Sato Kyogo (S) Pte Ltd and Another Appeal [2007] 4 SLR 413).

This paper highlights the Force Majeure events under the commonly used standard forms of contract in Malaysia. In this respect, the paper focuses on four (4) major Malaysian standard forms of contract that are (i) Public Works Department (PWD) Form 203A 2007/2010, (ii) Persatuan Arkitek Malaysia (PAM) Contract 2006/2018, (iii) Asian International Arbitration Centre (AIAC) Standard Form of Contract 2019 and (iv) Construction Industry and Development Board (CIDB) Standard Form of Contract 2000. The objective of this paper is to identify the provisions of construction contracts used in Malaysia that would trigger the application of force majeure and determine to what extent the provisions actually provide for a pandemic situation to be applicable in those contracts.

\subsection{Literature Review}

A situation of force majeure only arises where three elements are met, (i) the act in question must be brought about by an irresistible force or an unforeseen event; (ii) which beyond the control of the parties concerned and (iii) which makes it materially impossible in the circumstance to perform the obligations. However, a defence on force majeure will not succeed if the parties concerned merely find that obligation becomes more difficult or burdensome due to a political or economic crisis (M Zin, 2020).

A line has to be drawn between the operation of a force majeure clause and the applicability of the doctrine of frustration in common law because events outside the control of the parties which fundamentally change the circumstances of the contract would usually discharge the contract by frustration (Thamodaran \& Sri Kantha, 2020). Nevertheless, construction contracts contain provisions that excuse non-performance and exclude the applicability of the doctrine of frustration throughout the occurrence of the force majeure event (Halsbury's Laws of Malaysia-140 Building and Construction).

Non-performance of the contractual obligations short of frustration would normally be regarded as a breach of contract. Such failure would normally not excuse the parties from performing the contract. Such exclusion of the doctrine of discharge by frustration lies on the fundamental principles of contract law, i.e. principles of freedom of contract. Treitel (2004) and Muhammad (2020) observed that the exclusion of doctrine of frustration is plausible where the parties indicated that the contract is to remain despite the occurrence of the event that fundamentally changed the circumstances of the contract, which would discharge the contract if not but for the existence of the clause. Treitel further commented that the clause could also provide some relief if the occurrence of the event did not fundamentally change the circumstances of the contract of which the common law doctrine of frustration is not applicable.

Furthermore, the inclusion of a force majeure clause that is wide enough to cover some future unforeseeable events which have arisen will result in the common law doctrine of frustration will not be applicable at all. Parties are directed to that clause that they have inserted in their contract, which they are expected to make provisions of (Beale \& Twigg-Flesner, 2020). In the context of Malaysian Contract law, Cheong (2010) commented that the effect of a frustrated contract in common law and under Malaysian Contract Act 1950 is the same as section $57(2)$ is equivalent to the common law doctrine of frustration. Furthermore, section 66 provides for restoration of advantage received when a "contract becomes void", which refers to contracts that become impossible or unlawful under section $57(2)$.

In answering whether a different approach is needed to cater to contracts affected by the Covid-19 pandemic, Beale \&Twigg-Flesner opined that after analysing the French and German Civil Code and the overall practice of commercial contracts, appropriately drafted force majeure clauses coupled with rules governing post-formation unforeseen circumstances would be able to give a blanket cover for many contracts which suffers from the impact of the pandemic. Catch-all phrases should be narrowly interpreted (Schwartz, 2020). This can be seen in Article 8.33, Standard Form of Building Contracts (Without Quantities) 2017 of Asian International Arbitration Centre (AIAC), which is rampant in force majeure clauses in listing the events which would trigger the operation of the clause, such as "or other similar causes which is beyond the control of the parties".

However, certain force majeure clauses do provide for the suspension of the contract's performance based on "governmental laws" or "Act of God", which may be applicable in the Covid-19 scenario. Governments worldwide impose lockdown that restricts movement and shutting down business either through the force of law or recommendations to stay home. These governmental regulations might trigger the force majeure clause when the movement control is ordered, impeding free movement to perform the contract, at least during the duration of the order (Schwartz, 2020). Regarding the operability of force majeure in the Covid-19 situation as an "Act of God", 
Schwartz further opined that despite it depends on action or inactions of human beings, a pandemic might fall within its application, subject to the way it is drafted. His argument is simply that pandemic is an "Act of God", even if it is made worse by human spreaders and that its foreseeability does not matter.

\subsection{Methodology}

This research employs a qualitative research methodology in which the doctrinal approach has been used to provide detail and technical commentary upon and systematic exposition of the content of legal doctrine (Salter \& Mason, 2007; Abdullah, 2018). A legal analysis focuses on the primary sources of law, including cases, statutes, rules, legal principles and interpretation of construction contracts. Whenever applicable, reference also be made to the secondary sources of law that consist of books, journal articles and law reports.

The procedures of qualitative data collection in this research also includes adopting semi-structured interviews with the respondents. According to Bryman (2007) and Yaqin (2008), in-depth qualitative interviews would be the most appropriate method for collecting the data. This research is interested in knowing and understanding the respondents' point of view. The respondents were chosen based on a purposive sampling technique, particularly based on their construction industry duties. Alston and Bowles (2003) highlight that purposive sampling is chosen when there is prior knowledge about a particular group which is important to the study.

Data was collected based on the outcome of the interview with selected respondents from the construction fraternity. Several respondents were selected with a professional background in the building and construction industry, such as construction lawyers, arbitrators, adjudicators, architects, quantity surveyors and engineers. Questions for these semi-structured interviews were related to the effects of Covid-19 within the context of the Force Majeure event based on the commonly used Malaysian standard forms of contract to obtain insightful and practical views in supporting the doctrinal data.

\subsection{Findings and Discussion}

In the current global crisis, it is useful to rely on Lebeaupin v Crispin and Company [1920] 2 KB 714, where the Court referred to a quote from a French textbook that stated, "...war, inundations and epidemics are cases of force majeure...". The Court further added, "This is a wide definition, but I think that it usefully though loosely suggested not only the meaning of the phrase [force majeure] as used on the Continent but also the meaning of the phrase is often employed in English contracts". The Lebeaupin case was concerned with a clause containing a list of events which included "...any cause not under control" of the party but emphasised that the meaning of each cause turned upon the word used "a force majeure clause should be construed in each case with close attention to the words which proceed or follow it, and with due regard to the nature and general terms of the contract. The effect of the clause may vary with each instrument."

From the construction industry's perspective, construction contracts explicitly provide for provisions that excused non-performance under the application of Force Majeure, which usually grants an extension of time or right to damages. For example, Clause 23.8(a) of PAM Contract 2018 (Without Quantities) spelt out that extension of time may be granted in the event of Force Majeure, which is defined as "any circumstances beyond the control of the contractor caused by terrorist acts, governmental or regulatory action, epidemics and natural disasters" in the same conditions of the contract. The operation of the Force Majeure clause in this standard form of contract example is only within the defined limits. Fortunately, such an extension of time based on the defined Force Majeure limit is wide enough to cover global pandemic, i.e. Covid-19. In the absence of an explicit reference to 'epidemic/pandemic' as the listed events under the Force Majeure clause, parties would have to rely on the broad interpretation of other relevant clauses in the contract. For example, this is particularly the case concerning Public Works Department (PWD) Form 203A 2007/2010, Asian International Arbitration Centre (AIAC) Standard Form of Contract 2019 and Construction Industry and Development Board (CIDB) Standard Form of Contract 2000, which omitted a direct reference to epidemic/pandemic as the events triggering the Force Majeure clause. Alternatively, other relevant clauses may be of assistance to address the consequential effects of a pandemic such as 'lockout,' 'delays caused by suspension order from the appropriate authority,' 'delays caused by the appropriate authority,' 'change in legislation or law,' unforeseeable shortages in the availability of personnel or goods,' or 'delay by nominated sub-contractor or sub-suppliers.' Hence, all these clauses might come to rescue to excuse the non-performance of contractual obligation and entitle the contractor for an extension of time under the contract. However, the applicability of these clauses subjects to the interpretation of whether delays in completing a project are caused by governmental or regulatory action such as MCO, which is not attributable to the contractor's default. Moreover, the burden of proof lies on the party seeking an extension of time to demonstrate why pandemic delays the completion date.

However, this might be problematic when the Covid-19 pandemic spread globally because most construction contracts do not provide for a pandemic to be part of the events that trigger the operation of the Force Majeure clause. An example is the Standard Form of Building Contract (Without Quantities) (2017) issued by AIAC where while pandemic is not listed, it only provides that Force Majeure event must be an exceptional event or circumstance which is beyond the party's control and could not reasonably be provided against in the contract, which cannot be avoided or overcome and not substantially attributable to the other party. The Singapore Court of Appeal in RDC Concrete v Sato Kyogo [2007] 4 SLR 413 reiterated this position at para 54:

'The most important principle with respect to Force Majeure clauses entails, simultaneously, a rather specific factual inquiry: the precise construction of the clause is paramount as it would define the precise scope and ambit of the clause itself. The Court is, in accordance with the principle of freedom of contract, to give full effect to the intention of the parties in so far as the clause is concerned.' 
Table 1. Summary of the Force Majeure events in Standard Form Construction Contracts

\begin{tabular}{|c|c|}
\hline Standard Form Construction Contracts & Force Majeure events \\
\hline PAM Contract 2018 (Without Quantities) & $\begin{array}{l}\text { Clause 23.8(a) defined force majeure as } \\
\text { "any circumstances beyond the control } \\
\text { of the contractor caused by terrorist acts, } \\
\text { governmental or regulatory actions, } \\
\text { epidemics and natural disasters." }\end{array}$ \\
\hline $\begin{array}{l}\text { Public Work Department (PWD) Form 203A } \\
2007 / 2010\end{array}$ & $\begin{array}{l}\text { Clause } 57.2 \text { listed in detail what is } \\
\text { considered as force majeure, but } \\
\text { pandemics/epidemics are not listed. } \\
\text { Among others: war, nuclear explosion } \\
\text { and riot of employees. }\end{array}$ \\
\hline Asian International Arbitration Centre (AIAC) & Clause 9.34 provided for the \\
\hline Standard Form of Contract 2019 & $\begin{array}{l}\text { requirements of what may amount to } \\
\text { force majeure, but pandemics/epidemics } \\
\text { are not listed. }\end{array}$ \\
\hline $\begin{array}{l}\text { Construction Industry Development Board } \\
\text { (CIDB) Standard Form of Contract } 2000\end{array}$ & $\begin{array}{l}\text { Omitted reference to what amounted to } \\
\text { force majeure altogether. Hence, } \\
\text { omitting a direct reference to } \\
\text { pandemics/epidemics as the triggering } \\
\text { events for force majeure. }\end{array}$ \\
\hline
\end{tabular}

Arbitrators or courts usually tend to interpret the principle of force majeure narrowly to only cover the listed events. Therefore, the events considered as force majeure, which tolerate excuses from performing the obligations, should be drafted in clear language. Providing a clear illustrative, non-exclusive list of events that constitute force majeure strongly contributes to eliminating uncertainty in the contract (Polkinghorne and Rosenburg 2015). Accordingly, it is important to list explicitly the circumstances granting a contracting party relief from the performance. As a general rule, force majeure must be the sole cause of the delay. In the case of Seadrill GarnerOperations Limited v Tullow Garner Limited [2018] EWHC 1640, drilling operation were delayed by a drilling moratorium imposed by the Government of Ghana (a Force Majeure event) and Tullow's failure to progress a drill plan in areas unaffected by the moratorium (not a force majeure event). The Court held that the force majeure event must be the sole cause of the default. In contrast to the dearth of English cases concerning the issue of whether pandemic constitutes a force majeure event, the French Court recently has the opportunity to address this pressing issue. The recent decision by the Paris Court of Appeals in EDF v Total Direct Energie confirms that Covid-19 is considered a force majeure event. In that case, the Paris Court of Appeals ruled on the dispute between EDF and Total Direct Energie regarding the suspension by Total Direct Energie of the framework agreement for the purchase of nuclear electricity that they had entered into due to Covid-19 pandemic. The Court of Appeals upheld the earlier ruling issued by the Paris Commercial Court in May 2020 and found that the Covid-19 pandemic constituted a force majeure event justifying the framework's suspension as soon as this event occurred. The force majeure clause contained in the framework agreement stipulates that "force majeure means any external, irresistible and unpredictable event making it impossible to perform the Parties' obligations under reasonable economic conditions." According to this framework agreement, the President of the Commercial Court held that the occurrence of force majeure event results in the immediate and automatic suspension of its performance and the interruption of the annual sale of electricity. Based on the definition of force majeure in Article 10 of the framework agreement, the judge considered that 'the spread of the virus is obviously extraneous to the parties, is irresistible and was unforeseeable, as proven by the sudden nature and extent of its appearance.' In this condition, it was found that the requirements to establish force majeure events were met.

It is submitted that there must be clear and express provisions which provide in detail what would be the effect or relief if pandemic, of whatever nature, which affect the obligatory performance of the parties to the construction contract. Such provision would better facilitate the parties to determine their rights and liabilities should a situation like the Covid-19 pandemic arise again in the future. In the increasingly complex construction industry, the parties to the construction contract and their lawyers should be aware of the legal implications of the written agreement's bindingness and anticipate probable issues prior, during and post-project life cycle. The inclusion of a specified pandemic clause would maximise the benefits of effective management of construction risks.

\subsection{Conclusion and Recommendations}

There are differences in wordings of what would trigger the application of the force majeure clauses in the standard form construction contracts, which were highlighted above. These differences carry with it different application of the force majeure clause to the specific triggering events. There is no standard Force Majeure clause that can fit all cases and contracts. However, there are two options available for the parties when it comes to the drafting of a force majeure clause. First, a force majeure clause should clearly specify its list of events with a cross-reference to a defined force majeure term. In this regards, the list of events has to make a direct reference to 'pandemic and quarantine' to capture all the consequential loss arising from governmental or regulatory measures. Second, the parties may want to consider the inclusion of a stand-alone 'pandemic clause' in addition to existing force majeure events. A stand-alone pandemic clause should provide a specific definition of a force majeure event with a comprehensive description of its characteristics, leaving no room for ambiguity. By incorporating a closed list under the first option or a stand-alone pandemic clause under the second option, it will provide a legal certainty to force majeure events without relegating the parties to undergo other routes when seeking an 
extension of time. More importantly, both options should cover all possible consequences of the force majeure event. Such consequences include either resuming the work if the event resolves after a reasonable period, early termination if it is foreseen that the parties no longer able to resume the work or early termination if the event persists for a long period. In case of termination, the contractor is paid the due amount according to work performed up to the notice of termination.

\section{Acknowledgements}

This research is financially supported by Lestari Covid-19 Research Grant (600-RMC/LESTARI COVID/5/3 (026/2020) provided by Universiti Teknologi MARA (UiTM).

\section{Paper Contribution to Related Field of Study}

It is hoped that the study will contribute to a substantial knowledge in the area of Force Majeure by dissecting the legal uncertainty that surrounds the application of this civil law origin doctrine. It will thus serve to clarify the grey area of Force Majeure law caused by the exceptional event of a global pandemic. As the cases that link up pandemic to Force Majeure doctrine are scarce, the research output from this study will provide new knowledge as to how the construction industry or the Court will approach similar issue in the future. In addition, the output of this study will unfold 'a new epidemic/pandemic clause' for future construction contracts.

\section{References}

Abdullah, N.C. (2018). Legal Research Methodology. Thomson Reuters Asia Sdn Bhd.

Adebisi Raji, B. (2020). Alternative Dispute Resolution in Construction Disputes. In Yaakob, A. (et al.)(Eds.) Alternative Dispute Resolution: Law \& Practice. CLJ Publication, 767-768.

Alston, A., Bowles, W. (2003). Research for Social Workers - An Introduction to Methods (Second ed.). London: Routledge. 80.

Beale , H., \& Twigg-Flesner, C. (2020). Covid-19 and Frustration in English Law. In S. G. Long, Derecho de los Desastres: Covid-19. Pontificia Universidad Católica del Perú.

Bryman, A. (2007). The Research Question in Social Research: What is the Role? International Journal of Social Research Methodology, Vol.10, No. 1, 5-20.

Cheong, M.F. (2010). Contract Law in Malaysia. Sweet \& Maxwell Asia.

Halsbury's Laws of Malaysia - 140 Building and Construction. (n.d.). Impossibility and Frustration, 140.113.

Jon Miller (2020) Coronavirus and Construction Contracts assessed from URL: https://www.fenwickelliott.com/research-insight/articles-papers/covid- 19/coronaviruscovid-19-construction-contracts

M Zin, S. Covid-19 Measures: A Look into Defences in Response to Investment Treaty Claims, International ADR Forum (Inaugural AIADR Journal) Volume 1 Issue 1 August 2020

Muhammad, A. (2020). Relying on the Doctrine of Frustration During a Pandemic. 1 LNS(A)

Polkinghorne, M. \& Rosenberg, C. (2015) Expecting the Unexpected: The Force Majeure Clause. Bus. Law Int 16(1): 49-56.

Rahmat, N. E. \& Abdul Rahim, N. (2020). The Suitability of the Use of Mediation in settlement of Construction Disputes in Malaysia. In Proceedings of the International Law Conference - Volume 1: i-NLAC. DOI: 10.5220/0010054001180124, 118-124.

Salter, M. \& Mason, J. (2007). Writing Law Dissertations: An Introduction and Guide to the Conduct of Legal Research. Longman.

Schwartz, A. A. (2020). Contracts and Covid-19. Stanford Law Review Online, 73, 48-60.

Simon Tolson (2020) International Construction Business, Covid-19 and Reasons to Excuse Performance or Not. Assessed from URL: https://www.fenwickelliott.com/research-insight/articles-papers/covid- 19/international-construction-covid-19

Thamodaran, B.N. \& Sri Kantha, N. (2020). Is Covid-19 or the Movement Control Order A Force Majeure Event in Construction Contracts?. 1 LNSA cxiv.

Treitel, G. (2004). Frustration and Force Majeure, 2nd Ed. Sweet \& Maxwell.

Twigg-Flesner, C. (2020). A Comparative Perspective on Commercial Contracts and the impact of Covid-19 - Change of Circumstances, Force Majeure, or What? . In K. Pastor, Law in the Time of Covid-19. Columbia: Columbia Law School. 